\section{“Rule of Three"}

SIR,-Some official rebuke from the B.M.A. should surely be made to the Minister of Transport in his recommendation that three drinks should be taken before driving at Christmas. His " rule of three" must surely be the most imprudent advice given to motorists for many a decade. The rule of "none for the road" should always apply.-I am, etc.,

$\mathrm{I}$.ondon W.1.

GuY Beauchamp.

Sir,-We would urge you to use your influence to try to undo the damage done by the Minister of Transport in the television interview when he propounded his so-called Rule of Three. We are quite sure that the B.M.A. would never support the implication that it is safe as a general rule to drive after taking three drinks. To suggest, for instance, that a young man or woman of 18 is safe after taking three whiskies or three sherries is flying in the face of facts.

The only safe slogan is "If you drink, don't drive."-We are, etc.,

\section{A. Thomson.}

Ramsgate, Kent

$$
\text { D. A. J. NeDen. }
$$

\section{Urinary Infection in Childhood}

Sir,-I should like to take issue with some of the conclusions drawn by the authors of the article entitled "Clinical and Radiological Features of Urinary Infection in Childhood" (14 Novemher, p. 1222).

They describe as "unselected" the cases of urinary infection discovered in a paediatric out-patient department. The work of Kunin et al., which shows that significant bacteriuria is present in the urine of $1 \%$ of a schoolgirl population, makes it obvious that most urinary infections never reach hospital. They are presumably treated by the general practitioner, with or without a diagnosis, only a small proportion being referred to hospital. The cases referred to in the article are thus markedly selected in that they are children whose general practitioners have felt for one reason or another that they needed help with the managements of their illnesses. It seems obvious that if the actual incidence of urinary infection in children is taken then the proportion having radiolngical evidence of abnormality will be much smaller.

The noint I am making is that the conclusion the authors draw, that every urinary infection in a child should be investigated by full radiology, applies only to those urinary infections discovered in hospital and not necessarily to urinary infections in general practice. Surely the important point in dealing with any urinary infection is to obtain bacteriology of the urine, to institute therapy with an appropriate antibacterial agent for an adequate time, and then to have adequate follow-up bacteriology of the urine to ensure that it remains sterile. In any child with any important degree of structural abnormality relapse will occur, and this would then be àn indication for full investigation.

Thus many normal children would be saved the consequent discomfort and radiation hazard involved in intravenous pyelography and urethro-cystography, procedures which in the primary infection are of only prognostic value.-I am, etc.,

\section{Milngavie, Glasgow. KenNeth Harden. REFERENCE} ' Kunin, C. M., Zacha, E., and Paquin, A. J.,

SIR,-In an interesting and valuable paper on this subject by Dr. Jean Smellie and her co-workers (14 November, p. 1222) there is a bacteriological point on which they do not comment but which I feel deserves attention; this is the finding that of their 19 cases of urinary infection by proteus, all were caused by Proteus vulgaris.

This is surprising, since it is well known that the majority of proteus infections are due to Pr. mirabilis, and that infections with $\mathrm{Pr}$. vulgaris are comparatively rare. However, before discussing the matter further it would be of interest to know the criteria used to identify these strains as belonging to the species Pr. vulgaris. - I am, etc.,

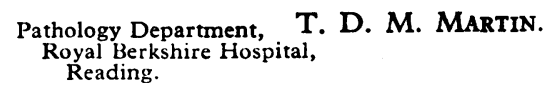

Sir,-In their important article on pyelonephritis in childhood (14 November, p. 1222) Dr. Jean M. Smellie and her coworkers give figures that suggest that a high proportion of affected children may acquire their infection in the neonatal period and remark on the difficulty of making this diagnosis in the newborn infant. A physical sign that I have found very useful in this connexion is the presence of palpably enlarged kidneys. This sign is often present before the baby is obviously ill and before pus appears in the urine and is often associated with a positive blood culture and jaundice: with treatment it regresses in a few days. When I have done an intravenous pyelogram subsequently no definite abnormality has been demonstrable, and in a baby who died of congenital heart disease, after regression with treatment, the kidneys were essentially normal in architecture though $50 \%$ heavier than expected. The nature of the swelling is not clear: renal-vein thrombosis, acute inflammation, and adrenal haemorrhage are possible causes. On a number of occasions the presence of this physical sign has enabled us to make an early diagnosis of neonatal septicaemia and to institute treatment before a baby became seriously ill.-I am, etc.,

Nuffield Neonatal Research Unit,

J. A. Davis

Institute of Child Health,
Hammersmith Hospital

London $\mathbb{W} .12$.

\title{
Lymphocytic Transformation
}

SIR,-The recent preliminary communication of Drs. M. W. Elves, S. Roath, and M. C. G. Israels (24 Octoher, p. 1051) reports their observation that the percentage transformation, after exposure to phytohaemagglutinin (P.H.A.), of lymphocytes from one patient with primary hypogammaglobulinaemia and six patients with hypogammaglobulinaemia secondary to chronic lymphatic leukaemia was significantly low. From this they speculated widely on the physiology of immune mechanisms. The finding in primary hypogammaglobulinaemia is contrary to two previous reports ${ }^{2}$ of normal transformation to P.H.A. (although immuno-fluorescence studies did not detect $\gamma$-globulin production in the transformed cells).

Schrek and Rabinowitzs and Quaglino found deficiency of response in some patients with chronic lymphatic leukaemia, though they did not give data of correlation with $\gamma$-globulin levels, as did Elves and his colleagues, who suggest that the low $\gamma$ levels in these patients (and in primary hypogammaglubulinaemia) might result from lymphocyte hyporesponsiveness. Before such a correlation could be regarded as a causative one other independent assessments of severity of the underlying disease would be needed. Also, from the technical standpoint, quantitative deductions from percentage trans-

Pre-treatment Serum Immunoglobulin Levels, and \% Lymphocytes Transformation Following Exposure to Two Non-specific StimuPre-treatment Serum Immunts to Antigens to which the Patients were Believed to be Exposed, in Five Patients with Primary Hypogammaglobulinaemia

\begin{tabular}{|c|c|c|c|c|c|c|c|c|c|c|c|c|c|c|c|}
\hline \multirow{3}{*}{ Patient } & \multirow{3}{*}{$\begin{array}{c}\text { Age } \\
\text { (yrs.) }\end{array}$} & \multirow{3}{*}{ Sex } & \multirow{2}{*}{\multicolumn{3}{|c|}{$\begin{array}{l}\text { Pre-treatment Serum } \\
\text { Immunoglobulins }\end{array}$}} & \multicolumn{10}{|c|}{$\%$ Lymphocyte Transformation } \\
\hline & & & & & & \multirow[b]{2}{*}{ Control } & \multicolumn{2}{|c|}{ Non-specific } & \multicolumn{7}{|c|}{ Antigens } \\
\hline & & & $\begin{array}{c}\mathrm{IgG} \\
\mathrm{mg} . / 100 \mathrm{ml} .\end{array}$ & $\begin{array}{r}\mathrm{IgA} \\
\% \text { of } \mathrm{St} \\
\mathrm{ma}\end{array}$ & $\begin{array}{l}\text { IgM } \\
\text { "Nor- } \\
\text { um } \\
\end{array}$ & & P.H.A. & $\begin{array}{l}\text { Staph. } \\
\text { Filtrate }\end{array}$ & P.P.D. & $\begin{array}{l}\text { Strep- } \\
\text { tolysin }\end{array}$ & $\begin{array}{l}\text { Tetanus } \\
\text { Toxoid }\end{array}$ & $\begin{array}{l}\text { Diph- } \\
\text { theria } \\
\text { T.A.F. }\end{array}$ & $\begin{array}{c}\text { Smallpox } \\
\text { Vaccine } \\
\text { (Lister) } \\
\end{array}$ & T.A.B. & E. coli. \\
\hline $\begin{array}{l}\text { A1 } \\
\text { A2 } \\
\text { B } \\
\text { C } \\
\text { D } \\
\text { F } \\
\end{array}$ & $\begin{array}{r}40 \\
40 \\
5 \\
62 \\
29 \\
2 \\
\end{array}$ & $\begin{array}{l}\mathbf{M} \\
\mathbf{M} \\
\mathbf{F} \\
\mathbf{P} \\
\mathbf{M} \\
\mathbf{M}\end{array}$ & $\begin{array}{c}80 \\
80 \\
7.5 \\
120 \\
2.5 \\
0.3 \\
\end{array}$ & $\begin{array}{l}1 \\
1 \\
0 \\
0 \\
0 \\
0 \\
\end{array}$ & $\begin{array}{r}9 \\
9 \\
3 \\
14 \\
25 \\
1 \\
\end{array}$ & $\begin{array}{r}<0.1 \\
<0.1 \\
<0.1 \\
1 \\
0.2 \\
<0.1 \\
\end{array}$ & $\begin{array}{l}61 \\
56 \\
80 \\
64 \\
85 \\
35 \\
\end{array}$ & $\begin{array}{l}37 \\
47 \\
48 \\
24 \\
\end{array}$ & $\begin{array}{l}<0.1 \\
\frac{3}{3} \\
4 \\
<0.1 \\
\end{array}$ & $\begin{array}{c}<0.1 \\
0.25 \\
5 \\
=\end{array}$ & $\begin{array}{l}\bar{Z} \\
\bar{z} \\
<0.1\end{array}$ & $\begin{array}{l}\frac{\overline{2}}{\bar{Z}} \\
=\end{array}$ & $\begin{array}{l}<0.1 \\
2 \\
1 \\
0.5 \\
1 \\
-\end{array}$ & $\begin{array}{l}\overline{<0 \cdot 1} \\
= \\
=\end{array}$ & $\begin{array}{l}- \\
\overline{1.5} \\
=\end{array}$ \\
\hline \multicolumn{6}{|c|}{ llthy adults } & $<0.1-0.5$ & 21-92 & $11-84$ & \multicolumn{7}{|c|}{ Range for immunized individuals approximately $1-8$} \\
\hline
\end{tabular}


formation at a single dose level of P.H.A. are unsatisfactory at present owing to many variables such as dose and batch variation, which are difficult to control.s

Although our preliminary studies confirm the hyporesponsiveness of some leukaemic lymphocytes, lymphocytic transformation with P.H.A. in five patients with primary hypogammaglobulinaemia has fallen within our normal range, as have the results from the other non-specific stimulant, staphylococcal filtrate (see Table). But we have also obtained significant transformation of cells from some of these patients using antigens to which they were thought to have been exposed. This contrasts with the negative results with antigens reported by Fudenberg and Hirschhorn. ${ }^{2}$ We regard the latter results as requiring further confirmation in a larger number of patients, but suspect that the final conclusion will be that there is a wide quantitative range of competence of the lymphocytic transformation capacity in patients with hypogammaglobulinaemia from essentially normal results (our patient M.C.) to failure even with P.H.A. (the patient reported by Elves and his colleagues). At present there is no evidence that this correlates with the deficiency of production of any one of the immunoglobulins which, themselves, vary independently in this group of patients. ${ }^{\circ}-\mathrm{We}$ are, etc.

N. R. LING. J. F. Soothill.

Department of Experimental Pathology.

University of Birmingham
Birmingham is.

REPERENCES

6 Hirschhorn, K., Kolodny, R. L., Hashem, N., and Bach, F., Lancet, 1963, 2, 305. udenberg, $H$. H., and Hirschhorn, K., Science,

schrek, R., 611. Rabinowitz, Y., Proc. Soc. exp.

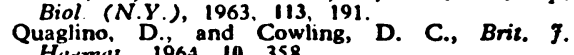
Huemaz. 1964. 10. 358.

s. Ling, N. R., Biochem. 9., 1964, $91,27$.

\section{Symptoms of Hypoxia}

SIR,-I was interested in the discussion of the effects of oxygen therapy on respiratory failure by Dr. D. C. S. Hutchison and his colleagues in the B.M.F. of 7 November (p. 1159). It is stated that, although difficult to distinguish from each other, hypoxia produces irrational and often aggressive behaviour, whilst hypercapnia leads to progressive drowsiness, both ultimately causing stupor and unconsciousness.

In this school we have had experience of over 500 cases of hypoxia in the last two years, as a training procedure for flying duties. Students are decompressed to 25,000 ft. $\left(7,772\right.$ metres) on $100 \% \mathrm{O}_{2}$ with an atmospheric pressure of $282 \mathrm{~mm}$. $\mathrm{Hg}$. They then breathe air $\left(\mathrm{Po}_{2} 58.5 \mathrm{~mm}\right.$. $\left.\mathrm{Hg}\right)$ with an estimated $\mathrm{P}$ alveolar $\mathrm{O}$ \% of $30 \mathrm{~mm}$. Hg. ${ }^{1}$ We have not noted symptoms of aggression during any of these tests, subjects becoming drowsy with inability to copy a piece of writing in about 4 minutes (extremes 1 minute and 12 minutes). Other symptoms are mild hyperventilation, subjective discomfort (" hot and sweaty" feeling, etc.), various visual difficulties, muscular twitching (incidence about 1 in 10), varying degrees of cyanosis, and mild euphoria (again about 1 in 10). We have never seen aggressive acti- vity such as shouting, struggling, or swearing (cf. $\mathrm{N}: \mathrm{O}$ anaesthetic).

I should like to suggest that if aggressive behaviour is frequently seen in hypoxic patients with respiratory failure, then this may be due to a combination of anxiety of the ill patient with the confusion of hypoxia, and is not a symptom of hypoxia per se. I am not familiar with cases of hypercapnia, but having read their description ${ }^{2}$ cannot imagine that I should be able to distinguish them from hypoxia on grounds of clinical observation.

One further point, we have had two cases of "oxygen paradox" in the 500 , the subject apparently getting worse for 30 seconds or so when his oxygen supply is restored. One of these was mild, the other (occurring in a trainee airline pilot) was severe with jactitating convulsions for about half a minute (it seemed more). There was no tongue biting or soiling of clothing, and recovery afterwards was complete without the

period of confusion associated with epileptic states. This occurred, incidentally, in the one subject who was writing nonsense after only one minute without oxygen at $25,000 \mathrm{ft}$. (7,772 metres).

Shenkin and Novack have described cerebral vasoconstriction resulting from raising the $\mathrm{P}$ arterial $\mathrm{O}_{2}$ above normal, and $\mathrm{I}$ can only suppose that such a mechanism is responsible for these occasional paradoxical reactions. Has this ever been noticed with patients in respiratory failure being placed on oxygen therapy ?-I am, etc.,

Aeromedical and Safety Training

M. F. HaWkins

Salisbury, Wilts.

\section{REFERBNCES} Boothby, in Aerospuce Medicine, 1961, ed. H. G.
Armstrong. Ballière, Tindall and Cox, Lon-

2 Gross, N. J., and Hamilton, J. D., Brit. med. F., 1963, 2,1096 Shenkin, H. A., and Novack, P., f. Amer. med.
Ass., 1961, 178, 390.

\section{Management of Respiratory Failure}

SIR,-It is pleasing that Dr. E. J. M. Campbell (21 November, p. 1328) agrees with us on so many points. The most imporant of these are: (1) That most patients with acute or chronic respiratory failure can be satisfactorily managed by controlled oxygen therapy. (2) That limits exist in terms of $\mathrm{PO}_{2}$ and $\mathrm{pH}$ at which this treatment should be abandoned in favour of tracheostomy and intermittent positive-pressure respiration. Dr. Campbell sets lower limits of safety $\mathrm{CPO}_{3}$ above $40 \mathrm{~mm}$. $\mathrm{Hg}, \mathrm{pH}$ above 7.22 ), but we feel it would be improper to comment on this until we have the opportunity to see his published evidence to support such limits. We were under the impression that he considered a $\mathrm{pH}$ above 7.16 as safe, as short a time as a fortnight ago, but we welcome his approach to our own still tentative figure.

With regard to the particular points he makes :

(1) The statement that "it is safe to assume that raising . . . the inspired $\mathrm{O}_{2}$ concentration to $30 \%$ will abolish dangerous hypoxaemia in these patients" is remarkable. These are gravely ill patients and measurements are more appropriate than assumptions. In a number of studies carried out since the publication several patients have had arterial $\mathrm{Po}_{2}$ levels below $50 \mathrm{~mm}$. $\mathrm{Hg}$ when breathing $30 \%$ oxygen and without previous exposure to higher percentages of inspired oxygen. Again in the published study high-flow oxygen therapy was being used to ensure that $30 \%$ oxygen was actually being inspired. The masks or nasal catheters used in clinical work are far less accurate and patients "on $30 \%$ oxygen" may be breathing $27 \%$ or lower. It would be helpful if Dr. Campbell would measure the arterial $\mathrm{PO}_{2}$ in his patients, particularly in the very ill ones, when " $30 \%$ oxygen" was being given.

(2) It is indeed true that the $p H$ only fell below safe levels when the inspired oxygen concentration was raised above $33 \%$, but it does not follow that this fall in $\mathrm{pH}$ would not have occurred if this concentration had not been exceeded. We have no information on this point, for in all our studies $33 \%$ oxygen was exceeded at some time. In any case, we consider that it is too early for any general conelusion to be drawn about this.

(3) We feel that Dr. Campbell's statement that if the inspired oxygen concentration is not raised above $33 \%$ and the $\mathrm{PCO}_{2}$ is below $100 \mathrm{~mm}$. $\mathrm{Hg}$ then $\mathrm{pH}$ and $\mathrm{Po}_{2}$ measurements are not necessary (and are in fact above 7.22 and above $40 \mathrm{~mm}$. $\mathrm{Hg}$, respectively) is such a sweeping and important claim that he should again publish his supporting evidence in detail as soon as possible. He has admitted that there are dangerous limits to these parameters, but he is confident that he need not measure them. He should also give data concerning the accuracy of the levels of oxygen administration with his present techniques.

On more general matters we would now entirely agree that higher levels of oxygen than $30 \%$ should never be exhibited in the initial stages. However, we ourselves would be extremely loath to give only $24.5 \%$ oxygen to anybody in very serious respiratory failure for a whole hour. Reference to Fig. 5 of our paper shows that $24 \%$ oxygen would raise the arterial $\mathrm{Po}_{2}$ by an average of only $7 \mathrm{~mm} . \mathrm{Hg}$, and this would result in a number of cases (i.e., Case 2 in our paper) having a degree of arterial hypoxaemia which even Dr. Campbell would consider dangerous. In fact we found it difficult to reconcile his initial assumption that $30 \%$ oxygen is necessary to abolish dangerous hypoxaemia and the routine procedure $(24 \% \quad 1$ hour, $28 \% 1$ hour, etc.) that he advocates.

With regard to the $\mathrm{PCO}_{2}, \mathrm{Dr}$. Campbell states that he does not await clinical evidence of hypercapnia but that he measures the $\mathrm{PCO}_{2}$ and then takes appropriate steps to avoid dangerous $\mathrm{CO}_{2}$ retention. Yet in the initial stage of his oxygen therapy he does not measure the arterial $\mathrm{Po}^{\prime}$, and we would like to know how he determines whether the arterial $\mathrm{Po}_{2}$ is above or below his stated danger level.

We would entirely agree that it should be everybody's aim to reduce the monitoring procedures in severe respiratory failure to a safe minimum. Dr. Campbell does not appear to appreciate that our prolonged and somewhat elaborate studies were entirely with 